\title{
Ortodoksi, ortopraksi og livsform
}

\section{Betragtninger over Niels Henrik Gregersens bog, Den} generøse ortodoksi. Konflikt og kontinuitet $i$ kristendommen. København: Eksistensen 2015. 523 s. Kr. 299.

\author{
Professor, dr. theol. \\ Bent Flemming Nielsen, Københavns Universitet
}

\begin{abstract}
The paper presents a revised version of an oral opposition given on February $24^{\text {th }} 2016$ occasioned by the presentation of Niels Henrik Gregersens magisterial book, Den generøse Ortodoksi. Konflikt og kontinuitet $i$ kristendommen, 2015, at the Faculty of Theology, University of Copenhagen. The opposition questions the book's use of the terms Christianity and Orthodoxy, and suggests alternatively a fresh look at the church being an institution and the church offices.
\end{abstract}

Keywords: Christianity - doxa - orthodoxy - Lutheranism - doctrine and faith.

Det var med glæde jeg sagde ja til at holde et oplæg ${ }^{1}$ og ønske til lykke i anledning af kollega Niels Henrik Gregersens nye bog, Den generøse ortodoksi. Der kan siges mange rosende ord om bogen, en del er allerede sagt og skrevet i diverse omtaler og anmeldelser, og jeg tilslutter mig gerne det allerede skrevne. Det er ikke hverdagskost at få præsenteret et dogmatisk værk på mere end 500 sider på dansk. Heller ikke selv om det drejer sig om en samling og forarbejdelse af forfatterens arbejder fra de seneste mere end 20 år, hvortil føjes en del nyt. Det er der grund til at ønske til lykke med til forfatteren og til at glæde sig over på fagets vegne.

Bogen er stor af omfang, og bogen er stor i sin prætention: Her skal ikke fedtes, her skal serveres marvfulde retter, her skal samtales med de store fra traditionen, Athanasius, Augustin, Anselm, Thomas, Luther, Grundtvig, Kierkegaard, Newman, Barth, Tillich og mange andre - de skal ikke glemmes eller gemmes bort på grund af en alt for beskeden modernitet, som har glemt sine egne rødder, og som har nedskrevet forventningerne til, hvad teologien i grunden handler om. Dette kan jeg også sige ja til. Nu er min opgave i dag ikke blot

1. Artiklen gengiver et oplæg ved bogpræstentationen den 24. februar 2016 på Det Teologiske Fakultet, Københavns Universitet. Artiklen bibeholder oplæggets mundtlige fremstillingsform, men er suppleret med noter og enkelte tilføjelser og korrekturer. 
at præsentere en bog, ej heller at give en form for samlet anmeldelse. Men opgaven er i henhold til aftalen med forfatteren at yde et vist modspil og en kritik. Jeg vil begrænse mig til bogens indledning og første kapitel. Samtidig skal det siges eksplicit, at jeg på denne korte plads ikke kan yde retfærdighed mod bogens mange nuanceringer og overvejelser.

\section{Kristendommen}

Lad mig begynde med at fortælle en episode fra for ca. 25 år siden, hvor jeg var på et obligatorisk lægebesøg hos min daværende læge. I samtalens løb, som berørte løst og fast, talte jeg på et tidspunkt om "kristendommen". Hvortil lægen kommenterede: "Sådan noget som kristendommen findes slet ikke. Der findes kun kristne mennesker". Med andre ord: "Kristendommen" er en abstraktion, en hypostasering, en konstruktion, måske en ideologi, som findes i hovedet på nogle mennesker - og i grunden ikke andre steder. (Jeg skal lige nævne, at jeg senere har skiftet læge - dog ikke på grund af hans mening om kristendommen.) Når jeg omtaler den episode, så er det fordi ordet, begrebet "kristendommen", spiller en gennemgående rolle hele vejen igennem i dagens bog, som når det eksempelvis hedder: "På samme måde forudsætter Kristendommen, at Gud har vist sig i Jesus og hans forkyndelse" (29). I sådanne sætninger er kristendommen en størrelse, der kan forudsætte noget, altså et subjekt. Det står også på forsiden: "Konflikt og kontinuitet i kristendommen". Der tales om kristendommens lære, kristendommens tradition (8), kirke og kristendom (8), om gammeleuropæisk og nyeuropæisk kristendom (10-12), om noget som hedder den repræsentative kristendom (20), om moderne kristendom (45) og også om en større kristendom (12). Når jeg hæfter mig ved denne udbredte brug af ordet kristendom, så er det for at forsøge at komme ind på livet af, hvad det er, der bevæger forfatteren til værket. Dette fører så frem til en problemstilling, som strejfes adskillige gange, især i indledningen. Den kan sammenfattes sådan: Kristendommen udtrykker sig ikke efter et tilfaldighedsprincip som "formlos spiritualitet" (7). Men kristendommen udtrykkes (udtrykker sig?) i en lare. Så vidt, så godt. Det er selvsagt ikke så enkelt, at den kristne tro blot består i at acceptere og tro en bestemt, en gang for alle vedtaget lære, som er fastlagt i bestemte formuleringer. For læren er selv omskiftelig, den flytter sig over tid, og bogen hævder med rette, at dette har sine gode teologiske grunde. "Der findes en før-refleksiv Kristus-tro, som går forud for ortodoksiens etablerede 
former for tro og tænkning", hedder det (19). Kristendommen er derfor "en selvbevagende fortolkningsreligion" (21), den udfolder sig i en refleksionskultur, som har sit grundlag i den tro, som går forud, og som kun tilnærmelsesvis kan formuleres sprogligt.

\section{Ortodoksi}

Vender vi os nu til det andet hovedord i bogens titel, så drejer det sig om ordet ortodoksi, som der reflekteres over i den indledende artikel. Her møder vi mange tankevækkende overvejelser over begrebet, dets historie og dets modsætninger, som kan være heterodoksi og kætteri. Kapitlet læser jeg som en forsøg på at rehabilitere begrebet om ortodoksi. Ja, mere end det: som et forsøg på at give begrebet nyt liv. Det spørgsmål, jeg til slut vil stille bogens forfatter, det er, hvorvidt disse to størrelser - kristendommen, som det udfoldes i indledningen - og så ortodoksi i grunden matcher hinanden? Tilhører begreberne samme felt? Befinder de to begreber sig på samme begrebslige niveau?

Det skal uddybes yderligere. Når jeg rejser spørgsmålet, så er det fordi jeg gerne havde set en lidt tydeligere distinktion i bogens overvejelser. Jeg tænker på distinktionen mellem kirkelare og teologiske meninger. ${ }^{2}$ Kirkelaren er den lære, hvorigennem et bestemt historisk kirkesamfund udtrykker og afgrænser sig. Det drejer sig for lutherdommens vedkommende først og fremmest om Den augsburgske Konfession, men omfatter også andre skrifter. Kirkelæren sikrer identiteten $\mathrm{i}$ et bestemt religionsfællesskab, en bestemt kirke, og afstikker dermed også grænserne for, hvad den pågældende kirke anser for ortodoksi. For folkekirkens og den forudgående danske statsreligions vedkommende har lærekorpus i praksis været fastlagt siden Reformationen, selv om den først blev defineret retligt i Danske Lov 2-1 fra $1683,{ }^{3}$ hvilket af jurister stadig anses for gældende bestemmelser. ${ }^{4}$

2. De følgende overvejelser er især inspireret af Hans-Martin Rieger, "Theologische Wissenschaft und kirchliche Lehre”, i: Gebundene Freiheit? Bekenntnistradition und theologische Lehre im Luthertum, red. Peter Gemeinhardt \& Bernd Oberdorfer (Gütersloh: Gütersloher Verlagshaus 2008), 261-284.

3. Eneste tilladte religion var "Den hellige Bibelske Skrift, det Apostoliske, Nicæniske og Athanasii Symbol og den uforandrede Aar 1530 overgivne Augsburgske Bekendelse samt Luthers lille Katekismus", cit. Preben Espersen, Kirkeret. Almindelig del (København: Jurist- og Økonomforbundets Forlag 1993), 39.

4. "Selvom Grundloven ikke selv opregner bekendelsesskrifterne, må det på den anførte baggrund [sc. Danske Lovs bestemmelser] vistnok antages, at det er udelukket at ændre folkekirkens lære ved indførelse af andre bekendelsesskrifter uden ændring af Grundlovens $₫ 4$ ", Espersen (1993), 60, jf. 83. 
Kirkelæren må holdes ude fra de omskiftelige, aktuelle teologiske laremeninger, som er karakteriseret ved aktualitet, og som dannes blandt andet på de teologiske fakulteter, men også i andre sammenhænge, i præstegårde, i diverse skrifter og i pressen. Teologiske læremeninger er udtryk for enkeltpersoners eller kirkelige grupperingers opfattelser. Det drejer sig om synspunkter, som der kan argumenteres for forhåbentligt på god videnskabelig basis, uden plagiat og uden at glemme at skrive de nødvendige henvisninger i noterne. De teologiske meninger kan udmærket forholde sig kritisk til kirkens officielle lære - ja, de er ofte tvunget til det, da det i kirkelæren drejer sig om historiske tekster. Eftersom teologi for at leve op til sit navn skal være andet og mere end blot repetition og recitation af konfessionens normative tekster, så åbnes der også for en kritisk distance. Hvis vi accepterer denne distinktion mellem kirkens lære og de teologiske læremeninger, så bliver spørgsmålet: Hvordan er forholdet mellem kirkelæren og de teologiske læremeninger? Og hvad har de med ortodoksi at gøre?

Til det første må man sige, at de begge har en fælles reference. Begge parter - både den identitetsgivende kirkelære og enkelte teologers (begrundede) meninger - relaterer sig til samme sag. Den fælles sag, som der på forskellig måde relateres til, omtaler bogen som nævnt bl.a. som en før-refleksiv kristustro (19). Dogmatisk ville jeg for min del godt præcisere det yderligere ved at sige, at den fælles reference er det forkyndte Guds ord eller kort sagt evangeliet. Lutherdommen lægger stor vægt på, at gudsforholdet er sprogligt medieret, hvilket ikke udelukker, men tværtimod indbefatter, at den sproglige mediering realiseres liturgisk. Guds ord 'høres' ikke alene som prædiken, men forventes at lyde både gennem den gudstjenestelige liturgi med salmesang og bønner og i de sakramentale handlinger. Det fælles referencepunkt, som er evangeliet forstået som Guds ord, er følgelig ikke identisk hverken med en bestemt tidstypisk teologi eller med et historisk formuleret dogme. Referencen er derimod et fælles konstitutivt tredje, som er det forkyndte og hørte evangelium. ${ }^{5}$

Dette kan også siges på den måde, at bekendelsesskrifterne bevidner et evangelium, de har en bestemt 'retning', som det fint hedder i bogen. Det samme kan siges om den teologiske meningsdannelse, om end det sker på anden vis og i andre former. I den teologiske refleksion udfoldes en teoridannelse, som i sig indebærer mulighed for

\footnotetext{
5. "In ihrer jeweiligen Lehrbildung beanspruchen beide [sc.Theologie und Kirche] [...] sich von einem gemeinsamen Dritten, dem Evangelium als Grund des Glaubens bestimmen zu lassen und konstitutiv auf es angewiesen zu sein. Das verbindet sie, während sie sich in der Art und Weise der Bezugnahme unterscheiden und dadurch zum kritischen Gegenüber werden.” Rieger (2008), 266.
} 
distancering og kritik også i forhold til dens egen bærende grund. Der er tale om to distinktioner:

a.) en "fundamental difference" 6 imellem bevidnelsen, teksten og udsagnet (både i Kirken lære og teologien) og det, som herved bevidnes (evangeliet, Guds ord, Treenigheden) samt

b.) distinktionen mellem kirkens læremæssige formuleringer og den aktuelle, kritiske, teologiske meningsdannelse.

Den første skelnen a.) mellem sagen selv og formuleringerne heraf spiller en vigtig rolle i bogen. Den implicerer, at al teologi må være præget af foreløbighed, samt at den må forsøge sig frem med nyformuleringer. Det betyder dog ikke, at alt flyder eller lader sig reformulere efter forgodtbefindende. Heri tror jeg, at Niels Henrik Gregersen og jeg er enige. Hvis vi går til det andet punkt, b.) så rejser det spørgsmål sig, hvad ortodoksi betyder og hvordan dette begreb forholder sig til den første af de to distinktioner. Mig forekommer det, at bogen forsøger at løfte sig op over disse distinktioner gennem den bredt anlagte tale om kristendommen. Men er det farbart? Hertil har jeg to overvejelser, den ene om forholdet mellem doxa og ortodoksi, den anden om ortodoksi, institution og embede.

\section{Doxa og ortodoksi ${ }^{7}$}

Jeg læser som sagt første kapitel som et forsøg på at rehabilitere og redefinere begrebet ortodoksi. Man hvad betyder det? Ifølge Meyers Fremmedordbog betyder Orthodoxi "Rettroenhed, Retlære, Kirketro, mods. Heterodoxi", ${ }^{8}$ altså læremæssige formuleringer. Det er imidlertid ikke ganske tydeligt for mig, hvad der menes med begrebet på centrale steder i bogens fremstilling, som når det $\mathrm{fx}$ side 22 hedder, at det drejer sig om "forsøget på at formulere ortodoksi som troens, håbets og kærlighedens livsform”. Jeg indrømmer, at jeg har vanskeligt ved at forbinde "livsform" og "ortodoksi", idet "livsform" vel angår sociale, mellemmenneskelige praksisser, mens "ortodoksi" vedrører bestemte diskursive udsagn. Skulle vi ikke hellere tale om ortopraksi, når det drejer sig om livsformer? Og jeg er en smule forvirret af henvisningen til Pierre Bourdieu (24), som vel sagtens skal bruges til at (re)definere doxa og ortodoxi. Det vil jeg opholde mig lidt ved. Bourdieu opererer ganske rigtigt med doxa som dét, der "goes without

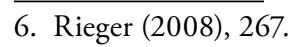

7. Afsnittet blev ikke fremført ved præsentationen, men er indført i artiklen.

8. Ludvig Meyers Fremmedordbog, ottende udgave (Kjøbenhavn: Gyldendalske Boghandel 1924), 725. 
saying, because it comes without saying", ${ }^{9}$ som bogen også citerer ham for. For Bourdieu er doxa udtryk for en social "naturalisering" af noget, som i grunden er arbitrært, men som i en given sammenhæng fremtræder som indiskutabelt. Doxa er det tavst forudsatte, som ikke kræver forklaringer, udredninger eller definitioner. ${ }^{10}$ En væsentlig pointe for Bourdieu er nu, at sådanne selvfølgeligheder er så selvfølgelige, at de almindeligvis skjuler sig for vores blik. De kommer først for en dag, når der opstår en krise. I krisesituationen vil der med nødvendighed opstå konflikter om, hvad det i grunden er, som i en given sammenhæng er selvfølgeligt. Bourdieu argumenterer her ud fra en klassekampstænkning, ifølge hvilken en krise angående doxa altid fører til en kamp mellem undertrykkernes og de undertryktes definitioner af, hvad der er det rette. Dvs. af, hvad der er ortodoksi og heterodoksi. Med denne kamp bevæger vi os ind på et nyt niveau. Bourdieu opererer med en overgang, "a passage", en bevægelse fra doxa til orthodoxy. Kampen om ortodoksien bliver til en kamp om formuleringer, distinktioner og bestemmelser. Med indførelsen af en hvilken som helst ortodoksi (politisk, religiøs, social) har vi med andre ord bevæget os fra universet af det tavst forudsatte til det, som udgør et sprogligt, diskursivt univers. ${ }^{11}$ Mens doxa i Bourdieus sammenhæng har med den sociale verdens selvreproducerende dynamikker at gøre, så betegner ortodoxi de "rettroende" formuleringer, som udvikles i kraft af de magtkampe og stridigheder, der pågår, når de involverede parter geråder i krise om det fælles grundlag. ${ }^{12}$

Når jeg har opholdt mig ved dette punkt, så skyldes det, at vi i bogen møder nogle formuleringer, som jeg har vanskeligheder ved at få klarhed over. Hvor hører talen om den generose ortodoksi hjemme, hvis ortodoksi - som Bourdieu hævder - altid forudsætter en eksplicit

9. Pierre Bourdieu, Outline of a Theory of Practice (Cambridge: Cambridge University Press 1977), 169, jf. 166.

10. "[W]hen there is a quasi-perfect correspondence between the objective order and the subjective principles of organization (as in ancient societies) the natural and social world appears as self-evident. This experience we shall call doxa, so as to distinguish it from an orthodox or heterodox belief implying awareness and recognition of the possibility of different or antagonistic beliefs." Bourdieu (1977), 165. Doxa udtrykker "the universe of that which is undiscussed, unnamed, admitted without argument or scrutinity", Bourdieu (1977), 170.

11. "[A] universe of discourse", Bourdieu (1977), 168, som bliver til gennem "the work of conscious systematizasion and express rationalization which marks the passage from doxa to orthodoxy." Bourdieu (1977), 169.

12. Som luthersk teolog kan man ikke undlade at tænke på Martin Luthers og Melanchthons formuleringer i de reformatoriske grundskrifter såsom Om kirkens babyloniske fangenskab og Confessio Augustana. Det drejer sig om formuleringer, hvormed de søger at overvinde en senmiddelalderlig, kirkelig doxa ved hjælp af radikalt nyformulerede sproglige bestemmelser. 
grænsedragning mellem det rette og det illegitime, det heterodokse? Hvordan skal bogens tale om kristendommen forstås? Menes der i virkeligheden teologien, der hvor der ofte står kristendommen, sådan at der er tale om en teologisk generøsitet?

\section{Institution og embede}

Efter min opfattelse så kunne bogens refleksioner have vundet ved at specificere talen om kristendommen, hvilket kunne være sket ved fx at knytte an ved ovennævnte distinktioner a.) og b.), samt ved en refleksion over det forhold, at der, hvor der for alvor er tale om ortodoksi - nemlig i de etablerede kirkesamfund - der eksisterer der notorisk også embeder og institutioner. Det skal jeg kort berøre her til sidst.

Talen om ortodoksi må i teologisk sammenhæng primært angå selve det læremæssige grundlag, bekendelser og liturgi, i et kirkesamfund. Den danske folkekirkes ortodoksi er ikke den samme som den russisk ortodokse kirkes, for eksempel. Her har vi med forhold at gøre, som står temmelig fast gennem århundrederne. De er ikke flydende, selv om fortolkningerne kan skifte. Selv reformationstidens lutherske bekendelser står urokkeligt fast, trods de kritiske indvendinger, der kan fremføres imod både det ene og andet punkt. En ændring af folkekirkens bekendelse vil ifølge juristerne tilmed kræve en grundlovsændring (Note 5). Ud af reformationens stridigheder er faktisk opstået en form for ortodoksi, som er afgrænset fra sin modsætning, heterodoksien. Nært forbundet hermed er et andet forhold, som er, at ortodoksi i et moderne samfund i Vesten kræver embeder og institution. Det indebærer, at selv om rammerne er vide og selv om friheden er stor, så kan der faktisk komme "en sag" ud af det, hvis fx en sognepræst i folkekirken udtrykker tilslutning til reinkarnationslæren. Det er en sag, som relaterer til embede og institution. Derfor er det da heller ikke en tilsvarende "sag" (i hvert fald slet ikke af samme karakter eller substans), hvis fx en teologisk lærer ved universitetet mener det samme. Hvad er forskellen? Forskellen ligger i institutionen og embedet. Der påhviler embedsindehaveren i kirken et ansvar, og der foreligger former for sanktionsmuligheder, som ikke ville kunne gøres gældende i forhold til alle andre medlemmer af kirken. Det betyder med andre ord, at ortodoksien er lokaliseret på et bestemt sted $\mathrm{i}$ institutionen, nemlig $\mathrm{i}$ et bestemt embede og dets konkrete forvaltning. I den danske folkekirke forholder det sig da også sådan, at loven om domstolsbehandling af gejstlige læresager kun omfatter tjenestemandsansatte og overenskomstansatte præster, provster og 
biskopper. ${ }^{13} \mathrm{Og}$ ingen andre. Teologiske professorer falder, til sammenligning, helt udenfor: $V i$ kan end ikke dømmes som hæretikere, eftersom universitetsansatte lærere ikke har et tjenstligt defineret læreansvar i kirken. ${ }^{14}$ Med andre ord: Ortodoksi er et begreb, som må lokaliseres i kirken, ikke på universitetet. ${ }^{15} \mathrm{Hvis}$ ikke dette fastholdes, så vil det betyde, at teologien (teologerne) og de teologiske uddannelser tiltager sig en religiøs magt, som rettelig burde ligge i kirkesamfundet, dets embeder og menigheder. ${ }^{16}$ Følgen vil være, at det ikke længere er til at skelne mellem universitet og kirke, for universitetet tenderer selv til at blive kirke - for nu at sige det lidt hårdt.

Jeg er meget vel klar over, at Niels Henrik Gregersen med sine overvejelser just ønsker at flytte på sådanne mere traditionelle synspunkter angående ortodoksi. Men jeg er ikke overbevist om, at det lykkes. Med disse bemærkninger vil jeg blot pege på vanskelighederne ved den forståelse af kristendom og ortodoksi, som denne omfangsrige og tankevækkende bog generelt plæderer for. Jeg vil slutte med at gentage spørgsmålet om bogens to hovedord: Befinder talen om "kristendommen" og "ortodoksien" sig i grunden på samme begrebsmæssige niveau? Er bogens tale om kristendom og ortodoksi tilstrækkeligt præcis til, at den bringer os videre i retning mod fornyende indsigter?

13. Lov nr. 336 af 14 . maj 1992, $\$ 1$. En helt anden problemstilling er det, at det kan betvivles, hvorvidt denne lokalisering fuldt ud stemmer overens med Martin Luthers oprindelige synspunkt vedrørende menighedens læremæssige ansvar, sådan som det kommer til udtryk i skriftet fra 1523 "Hvorledes Skriften forklarer og beviser, at en kristen forsamling eller menighed har ret eller magt til at bedømme enhver lære og til at kalde, indsætte og afsætte lærere”, WA 11, 408-416. Den juridiske præcisering af præsternes embedsforpligtelse har næppe sin forudsætning i den tidlige Reformation, men snarere i den senere historie, hvor de lutherske præster blev folkeopdragere, og lutherdommen havde udviklet sig til en fyrste- og statskirkelig ramme om religionen.

14. Sådan er det i det mindste i Danmark. Hvis teologiske lærere beskikkes som sagkyndige ved en sag ved den gejstlige domstol, så skal de være medlemmer af folkekirken, jf. $\$ 6$ i Lov af 1992, hvilket jeg vil betragte som et udtryk for den lutherske tanke om menighedens læreansvar og kaldelsesret, jf. Rieger (2008) 282.

15. Talen om ortodoksi på universitetet er i forhold hertil afledt og sekundær, som når der fx tales om marxistisk ortodoksi.

16. At kirken til sine embeder kalder personer, som har gennemført en kvalificerende uddannelse ved et universitet, er en sag, som efter min opfattelse ikke ændrer ved disse grundlæggende forhold. 